\title{
Concept of Jean-François Lyotard on Postmodernity Situation and the Problem of Science Legalization - From Marx Philosophy's perspective
}

\author{
Dr. Nguyen Trong Nghia \\ University of Social Sciences and Humanities - Viet Nam National University Ho Chi Minh \\ City (VNUHCM -USSH), Vietnam. \\ E-mail: ngtrongnghiabd@hcmussh.edu.vn \\ D.O.I - $10.51201 /$ JUSST/21/05185 \\ http://doi.org/10.51201/JUSST/21/05185
}

\begin{abstract}
In the flow of contemporary world history, the interactions between modern and postmodern values continue to be more bold, influenced by the leading person of information technology and communication. In the "most developed social situation", many postmodern theorists seek to overcome traditional philosophy, including Marx's philosophy. Human ideas will have another turn called "postmodernity", but in the end, new forms of this way are still stuck. Moreover, Marx philosophy remains a preeminent legacy in at least two aspects posed by postmodernism: epistemology and the question of truth. It was realized, once again, that returning to Marx was an effective means of the ideological ailments of the new age.
\end{abstract}

Keywords: Jean-François Lyotard, Postmodernity Situation, problem of Science, Marx Philosophy's

\section{Introduction}

Postmodernism is associated with the name of the French philosopher, Jean-François Lyotard (1924-1998). His description and evocation of the postmodern situation, and at the same time putting it on the philosophical forum, has made him famous. Among the notions that he mentioned about postmodernism, there are notions of the appearance of knowledge, science, the non-separation between modernity and postmodernity, as well as the continuation of the main idea of modernity by postmodernity. In the context of the era of information technology and telecommunications, due to the crisis of the great narratives, especially in the legalization of knowledge and science, Lyotard advocated for the minor narratives. This attitude, indirectly shows that he rejected the doctrines of many philosophers in the past, such as: Hegel, Marx, etc. However, as a result, it fell into a deadlock, unable to overcome current philosophy, in the concept of human authority, the relationship between the subject and the object. This article wishes to bring a way of interpreting the problem from the perspective of Marxist philosophy.

\section{Research Methods}

Method and Data

The paper's approach is based on the worldview and the methodology of Marxist philosophy, and at the same time uses specific research methods such as analysis and synthesis, logic and history, 
inductive and interpretation, abstraction, generalization, comparison, comparison and literary methods for research and presentation.

\section{Literature Review}

Postmodern has the Latin origin of the word modern: modo, meaning "right now". If translated word for word, postmodern means "after now". That is why the postmodern is understood as a part of the modern. Historically, the modern has always clashed with what came right before it. In this sense, the modern always means post-something-something. The modern ends up in conflict with itself and inevitably becomes postmodern.

Jean-François Lyotard (1924-1998), one of the pioneers who laid the foundations of postmodern theory, explained the etymology of the term "postmoderne". According to him, postmodernism contains the prefix "post-" representing the post (after), the future, and the word "modo" means "before". This etymology is a paradox. The postmodern model will be understood as a paradox. It is of the modern, is included in this and it even stands before it: "A work can only become modern if it is first and foremost postmodern." Therefore, postmodernism is always in a nascent state.

Because the prefix "post" comes before "modern", the concept of post-modern is often confusing. In general, postmodernism is used in many mixed or harmonious ways of some or all meanings, such as: result, effect, precedent, offspring, development, denial. or the refusal of the modern.

Postmodernism has a postmodernism derivative relationship. And it is also difficult to statistically how many works on postmodernism and postmodernism. The authors have a separate approach and concept on these concepts. The scientific literature about them is increasing and difficult to cover.

Simon Malpas, lecturer at the University of Edinburgh (Scotland), has studied the theories and definitions of postmodernism, postmodernism, exploring their impact in areas, such as: identity, calendar history, art, literature, culture and philosophy. In an attempt to map the various forms of postmodernism, and the contradictory postmodern experiences in Western countries and the developing world, Malpas defines the connotation and appearance of the modernism and postmodernism, modernism and postmodernism, among other relations of subject, history, politics. On that basis, in The postmodern, Simon Malpas established many concepts of postmodern as a form of thinking about the modern. It may indicate a new aesthetic system (I.Hassan), a certain state (J-F. Lyotard), cultural form (S.Connor), a cultural theme (F. Jameson), and so on.

Lyotard lyotard more clearly indicates the essential sign of the postmodernism: "postmodern as incredulity toward metanarratives. This incredulity is undoubtedly a product of progress in the sciences: but that progress in turn presupposes it. To the obsolescence of the metanarrative apparatus of legitimation corresponds, most notably, the crisis of metaphysical philosophy and of the university institution which in the past relied on it (Lyotard, J-F, 1984, p. xxiv).

Metaphysical (meteranarrative, meteraricits) are theories that are considered universal, absolute or ultimate, used to validate or legitimize any project of science or politics.

In the first part of the Postmodernism Answer to Children (Le postmoderne expliqué aux enfants), titled "Answering the Question: What is Postmodernism?", which is a letter addressed to Thomas E. Carroll May 15, 1982, when Lyotard was in Milan, he stated: So what is postmodern?... Obviously it's part of modernity. For postmodern everything that was once 
accepted, even yesterday (the fad, as Petronius used to say), is suspicious... That is why postmodernism should not be understood. as the last stage modernism, but as the state itself arises, and the state is constantly and constantly. Another aspect of this book is Lyotard' response to postmodern misconceptions such as anti-modern, anti-modern.

In Vietnam, researchers also share the concept of postmodernism, with similar concepts. For example, Le Huy Bac (2017), the author of Postmodern Literature, Theory and Reception, defined: "Postmodern is a concept indicating a certain period in the economic, scientific, technological and high-art development of the society. It comes about when modern theories have become old, have become great narratives” (p.23).

And Nguyen Uoc (2009), in the Philosophical Topics, when annotating the postmodern concept (CN), noted: "... seen as a reaction against childish and excited belief in progress brought about by reason, and against belief in objective and scientific truth... skepticism of the rhymes. modernity, including evidence on a large scale of Western society and its belief in its apparent progress in Kant, Hegel or Marx” (p.460).

Postmodernism was born with certain conditions ${ }^{1}$. That condition is called the postmodern condition by Lyotard and some postmodern philosophers - the condition that makes modern theories old.

“... It designates the state of our culture following the transformations which, since the end of the nineteenth century, have altered the game rules for science, literature, and the arts. The present study will place these transformations in the context of the crisis of narratives" (Lyotard, J-F, 1984, p. Xxiii).

The timeline of the social transition that led to the formation of postmodern conditions was determined by Lyotard to begin at least in the late 50s of the twentieth century, when Europe ended the process of social reconstruction, after the Second World War. That condition associated with rapid social changes led to a "fundamental" crisis, forming a new spirit postmodernism (esprit postmoderne). Philosophically, Lyotard points out, it is the crisis of science and knowledge in general, when its status and rules are legitimized (légitimer) through metadiscours, by the way to invoke the great narratives (grand récit) like the dialectic of the Spirit, the hermeneutics of meaning, the liberation of the rational or the working subject, etc.

Martin Irvine - Curator of Communication, Culture \& Technology - Georgetown University, in "The Postmodern","Postmodernism", "Postmodernity" - Approaches to Po-Mo, exploring another dimension: Post-modernism postmodernism is related to the perception of social and cultural transition after World War II and the emergence of popular consumer culture in the 1960s and 1970s.

In the postmodern condition, skepticism arises about the super narratives, about the universal theory, because of its aging. Due to the advancements in techniques and technologies since World War II, human needs go beyond great tales. Corresponding to that is: "the crisis of metaphysical philosophy and of the university institution which in the past relied on it. The narrative function is losing its functors, its great hero, its great dangers, its great voyages, its great goal” (Lyotard, J-F, 1984, p. xxiv).

Losing confidence in the super narrative affects the way we view and perceive science, philosophy, art and literature. Small stories became suitable for the interpretation of social

\footnotetext{
${ }^{1}$ It is up to each author that condition is translated as condition, situation, condition or situation.
} 
transformations and political problems. This is the driving force behind post-modern science and philosophy, Lyotard said.

When the great narratives disappear, at the same time people also lose faith in science's ability to seek truth, so there must be another way of legitimizing its efforts. In the condition that information technology and communication are holding the upper hand for all aspects of social life, the legalization of science must be linked with informatics in order to organize, store and process information in the system. computer systems, through the research and practice of techniques involved in the simulation, transformation and reproduction of information, into computer data. Then, new knowledge is considered useful.

The presence of postmodernism attracts the attention of Western philosophers not only in the questioning of its legitimization of science and knowledge, but also in its criticism of Marx in general, Marx philosophy in particular.

\section{Research results}

Lyotard's thought about postmodern conditions associated with intellectual products has its origins in the context of Western society in general, in France in particular, in the 60s and 80s, twentieth century. That was the period when people witnessed a broken state of traditional values, the crisis of the relationship between people and people in the family and the society, and the economic crisis that negatively affected the commune associations, especially widespread unemployment; the whole society embraces egoism, inequality. In France, despite the government's slogan set out as "Equality of opportunities - Égalité des chances", that is to create conditions for all to be equal in all aspects. However, in reality, French society is a selfish, harsh society (individualisme et très dure - Hirigoyen) and very clear class distinction (Bourdieu). Therefore, since the 1960s, there has been the anti-cultural movement (Contre-Culture), anticonservatism, old, “anti-progressiste” (“anti-progressiste”).

According to Lyotard, in the postmodern condition, the theories dating back to the Enlightenment, in the West, have all broken down and the computerized society has transformed the destiny of knowledge. Therefore, the state of knowledge and its status in current society are seen as the goal of his research in The postmodern condition (La condition postmoderne). Because of this importance, Lyotard has attached the sub-title: A Report on Knowledge (Rapport sur le savoir).

Knowledge in modern society is highly developed in relation to the social presentation method. The postmodernist author divides society into two models: society forms a functional whole and society forms two poles. The first model representative is Talcott Parsons ${ }^{2}$ (1902-1979) of the same school, while the latter one of Marxism and Marxism admits the principle of class struggle and dialectic, as the two operating the system. most of society. Lyotard considers these two models with two major types of social discourse, taking place since the nineteenth century, as great narratives, whether they are in terms of system theory (of Parsons) or critical (Marx), is seen as a message that spreads the ideal of human liberation, or as a non-profit ideal. And, the great narratives really disintegrate in postmodern conditions. On the basis of citing the opinions of many delegates, Lyotard proves the "paranoia" of the Parsons model and to "get rid of its attraction", it is necessary to rely on the "principle of class struggle" in social theory originated

\footnotetext{
${ }^{2}$ American sociologist, professor at Harvard University. He spends a lot of time and effort researching and understanding what conditions to keep the unity of the social system in the face of environmental changes, as well as what conditions to ensure survival of the system.
} 
from Marx. However, under the eyes of him and other delegates, such as JPGarnier (born October 31, 1947), or E.Bloch (1880-1959), G.Raulet (born August 9, 1949), then this model also "loses all radicality" and is degraded to a "utopia", a "hope", part of which because "only takes into account the critical function", does not accept. "An integrated whole" and rigid the principle of dispute (principe de contestation), especially because "does not know what happens to knowledge" as well as "ignorance of the society in which it takes place".

Knowledge in a computerized society, becoming a commodity, can be exchanged in the market and profitable like other goods, so it has been removed from human copyright. German philosopher Jurgens Habermas (born June 18, 1929) shared this argument in his essay La modernité: Un projet inachevé (Modern: a project in progress), which was later developed by Habermas as a Comment: Le discours philosophique de la modernité (Philosophy of modernity) and La pensée post Métaphysique (Post-metaphysical thought).

The postmodern period is the period when science and information technology hold "absolute sovereignty" over all fields of information; when knowledge became a commodity of trade, the condition of knowledge (condition du savoir - Lyotard's use) had to change.

American sociologist, professor at Harvard University. He spends a lot of time and effort researching and understanding what conditions to keep the unity of the social system in the face of environmental changes, as well as what conditions to ensure survival of the system.

Lyotard explain as soon as societies enter the post-industrial era and the culture entered the era of postmodernism called knowledge change its position. The very impact of technological changes in all fields of science and engineering on knowledge is very great, changing its nature. In its turn, knowledge "transformation in the nature of knowledge, then, could well have repercussions on the existing public powers, forcing them to reconsider their relations (bot de jure and de facto) with the large corporations and, more generally, with civil society” (Lyotard, J-F., 1984, p. 6).

According to Lyotard, the factors that force States to reconsider their roles, since the late 1970s of the twentieth century, include: The reopening of the world market, the return of economic competition is very excitement, the complete abolition of American capitalism, the collapse of the socialist path of choice, the possibility of opening the door to changes in the Chinese economy, and so on.

In postmodern conditions, people destroyed large documents (grands récits), hypertext (meterarécits), advocates to preserve and promote the diversity of linguistic terms in small texts (petits récits) or micro-text. When it comes to grands récits or meterarécits, people refer to the great theories, including the theory from the Enlightenment, the Hegelian philosophical system, the Marx philosophical system. Appreciation of petits récits is essentially the promotion of linguistic theories, such as the Linguistic Game Theory of Wittgenstein (1889-1951), in order to negate the universality, emphasize the specificity and variation of the game; is to exaggerate the disintegration of social bonds and focus on small masses, groups, even individuals like atoms.

Postmodernism until now is not a new term, but to grasp it is indeed not easy, not because of the dangerous topic but because of its inconsistency. On the one hand, it follows the thought of the progressive currents of modern times, from the late nineteenth century to the early twentieth century; on the other hand, it opposes the modern spirit of modern rationalism, Enlightenment philosophy, negates metaphysics, separates the unity of the worldview and methodology of traditional philosophy. 
Western philosophers have varied views and assessments of postmodernism. Irving Howe (19201993) and Harry Levin (1912-1994) said that in postmodern conditions there is a phenomenon of cultural degradation. On the contrary, for Susan Sontag (1933-2014), Leslie Fiedler (1917-2003) or Ihab Hassan (1925-2015), postmodernism marks a process of development, etc.

With the view of Marx philosophy, it is possible to evaluate postmodernism in the following aspects: absoluteization of relative truth; the legalization of science, philosophy; deny Marxism in general, Marx philosophy in particular.

The question of truth, man, has been, since ancient times, haunted endlessly by its complexity and multifaceted nature. Philosophers constantly contemplate and contemplate the nature of truth, with the desire to possess a perfect definition of the concept of truth. But it is a difficult process, when it is not easy to impose individual views on a definition.

In the postmodern era, many philosophical debates revolved around the concept of truth, but in the end, it does not present anything new than what the ancient philosophers had discussed. Aristotle (384-322, BC) argued that the compatible relationship between "concept" and "things"; for Hegel, truth is associated with the accomplishment of perfect perception; for William James (1842-1910), truth means the relationship brings real results; George E. Moore (1873-1958), with the correspondence between "figure" and "real"; and the existentialist philosopher Martin Heidegger (1889-1976), truth is synonymous with freedom; while Alfred Tarski (1901-1993), with semantic concepts, and so on.

From the time of Socrates (469? - 399 BC), people have debated the question of whether truth is relative and subjective or truth is absolute and objective. Even Gorgias (483-375?, BC), a delegate of the Speechism, went even further when "doubting" the existence of truth in reality.

The proponent of the concept of relative truth is Protagoras (480-410? BC) of Avdira. He said that it is the imperfection of the senses that human knowledge about the world is difficult to complete and true, even though human cognitive processes are sometimes supported by devices. Therefore, the little piece of knowledge based on fragmentary sensory experience will be very different for each person. Knowledge, therefore, is by nature an opinion of the individual, is a subjective form of truth. And because truth is a subjective opinion, according to the Protagoras interpretation, truth depends on the subject of perception.

With the rise of rational thinking, has established for the Enlightenment a theoretical scientific model for all aspects of truth. The belief in scientific data and the contributions to the idea of relative truth must include the German philosopher Immanuel Kant (1724-1804), whose work Criticizes pure reason (1781). And, a new variant of it is identified in the era of computerization and new media theory.

According to Lyotard, in the postmodern condition, whether science or any other intellectual field, the legitimization of the combination of modernity with universality, unity, unity, and determination. is denied, and instead is an affirmation of specificity, difference, variation, pluralism. Since this is consistent with the essential transformation of knowledge, knowledge becomes information and commercialization, that is, it takes the effectiveness of knowledge as the standard, which is purely relative. Therefore, it is not uncommon for Lyotard to return to Ludwig Wittgentsein's "Game of Linguistics" theory, because of the relativity of linguistic expression, the meaning of knowledge expressed by expressive language is associated with sign processes. fruit use it. Furthermore, this theory does not admit the determinism and common 
rationality of the rule, but emphasizes the specificity and variation of the game, so it is impossible to exist of the "great narrative" ,"Super narrative".

The transition from modern to postmodern is related to the ideology of Frederick Nietzsche (1844-1900). With the notion that all knowledge (including science) is a matter of views and views, Nietzsche is considered as the idol of postmodernism. Many postmodern philosophers such as: Lyotard, Foucault (1926-1984), Rorty (1931-2007) have built the theory based on the work of Nietzsche. Nietzsche's farewell to Hegel, according to Gilles Deleuze (2010), which meant rejecting absolute knowledge, a holistic thought, and denying "great narrative", made Lyotard more consistent with "minor narrative" (p.223-227). From this point of view, it can be seen that there is a figure of Derrida (1930-2004) in their appreciation of personal sentiment, experimentation, imagination as the source of creativity and the standard of truth, of game.

The philosophical war with objective truth and therefore, with objective knowledge, according to them, leads to man in the postmodern situation completely opposed to all claims of objective truth and great truth. for. Such an argument inevitably leads to the rejection of theories that admit objective truth. Marxist philosophy is among them, though, this philosophy has a dialectic view of objective truth and subjective truth. Clearly, whatever the "situation", the denial of objective truth cannot fail to go to subjectivism and relativism. Postmodernism cannot avoid that "chasm". The presence of postmodern to a certain extent reflects the desire for a transformation of modern Western philosophy, from Nietzsche onwards. If no objective truth exists, and if the study and validation of science as well as philosophy through efficiency is done by a "game of language" then the determination of the true / false meaning of truth reason and error do not belong to its content, then naturally will lead to the conclusion that all beliefs must be considered equally plausible. Lyotard explained: "Those are games whose relevance is not in truth (vrai), or in truth (juste), or beauty, etc., but in effectiveness. Technology is therefore a game pertaining not to the true, the just, or the beautiful, etc., But to efficiency: a technical "move" is "good" when it does better and / or expends less energy than another" (Lyotard, J.F., 1984, p.44).

Thus, the correct term for this form of postmodernism is pluralism. With pluralism, it is impossible to say that one is right and that other opposing beliefs are wrong, or worse. It is the admission of pluralism that postmodernism falls into the stance of skepticism (scepticism) and nihilism (nihilism).

Consequences from the postmodernist conception of relativistic truth, pluralism, make it, after a period of existence, to a standstill, not really transcending modern philosophy, especially philosophy. Marxist study of the real human authority in relation to the objective world, as well as the dialectic between the subject and the object.

On the pluralism standpoint, postmodernism inevitably denies the unity of the world, considering the world as random combinations of elements, elements; of its methodology is to exaggerate, exaggerate, absoluteize the diversity, the particular, the difference which has always been present in the world, is the opposite of the common and the private - which have an argument witness in every thing, phenomenon. Thus, we can also see that the essence of pluralism in postmodernism is empiricism. It describes the world eclectically as multiple heterogeneous processes separated from each other and, in principle, not on a single common basis.

Remember that, more than 130 years ago, when natural science had a new development, many philosophers hastily broke with dialectic, F.Engels himself pointed out the consequences of this action as: “... with the drop of Hegenism one threw dialectic as well - right at a time when one 
could not fail to accept the dialectic nature of natural processes, at a time when therefore only there is a new dialectic that can help natural science overcome the difficulties of reasoning. As a result, people become irreversibly victims of old metaphysicalism. (Mark, C. \& Angels, Ph., 2004, p. 489).

There is one indispensable problem: Postmodernism.

Postmodern theorists (Baudrillard, Lyotard, Harvey, etc.) assert that the postmodern condition is the most developed social one, with features of computerization and telecommunications. That very foundation arose a post-industrial society, and its supporters also asserted that it was the postmodern era, forming a new state of history and a new form of culture. This new situation required new concepts and theories.

According to them, technologies and techniques such as computers and communications have a great influence on the transformation of knowledge nature and changes in socio-economic systems, post-modern social form. . However, in terms of interpretive Marxist theory, this period, in fact, is a stage of development at a higher level of capitalism, marked by the penetration of capital at a greater level. and the globalization process is broader and deeper. This period inevitably increases cultural fragmentation, new ways of experience, subjectivity and mass. Postmodernism carries the bourgeois worldview model, nothing more and no less. Focusing only on the computerization and telecommunications characteristics of social development, postmodern representatives tried to deny the causes of society, class conflict, contradictions of the new age The modern social department has been scientifically and practically interpreted by historical materialism.

Frederic Jameson (born April 14, 1934) was an American literary critic and Marxist political theorist, even in a polemic titled Postmodernism, or the Cultural Logic of Late Capitalism. modernism or the cultural logic of late capitalism), published in New Left Review, 1984, affirms: Modernism and postmodernism are cultural forms parallel to the fish phases. specialism of capitalism. Postmodernism corresponds to the period of consumer capitalism, closely associated with electronic and atomic technology. He sees the postmodern situation as the "logic of late capitalism". Jameson saw the "postmodern skepticism" of metaphysics as a way of experience derived from the intellectual labor conditions produced by the late-stage capitalism. His topics of interest were anti-political, relativistic and anti-evolutionary tendencies of the times.

The theory of the postmodern postmodern situation supersedes "small narrative" and opposed "great narrative". This theory considers Marxism in general, Marx philosophy in particular, as a form of narrative, a kind of "great narrative". Therefore, in analyzing the "great narratives to validate knowledge", having pointed out two forms of legalization, one is political and the other is philosophical, Lyotard argues. Marxism "wavered" between the two ways of legalization: The first: the Party held the university position, the proletariat held the position of the people or the humanity, the dialectical materialism held the position speculative idealism, etc. from there "is Stalinism" and its relationship with the sciences serves as a "quote from the metaphysical service of the path to socialism. as the equivalent of Spiritual Life "; The second way: Marxism can develop as critical knowledge, "socialism... is the creation of the autonomous subject... to give the proletariat"... "the means to liberate oneself. from corruption and oppression, it was the 
Frankfurt stance ${ }^{3}$. Relying on the fact of the rightist, leftist, postmodern theory that denies the revolutionary and scientific nature of Marxism, because they rely on the argument "the decline of the narratives", "Great narrative loses its credibility", regardless of the way of integration: "selfcriticism or self-liberation".

A science that does not find its legitimacy is not real science, Lyotard emphasized; it falls on the lowest level - the level of ideology (deception) or even the means of power.

Anthony Giddens (b. 1938), an English sociologist, agrees that there are very specific changes that mark our present era, but it is not "postmodern", but only is the "modern era of radicalization". With the "The Third Way", ambitious to replace the traditional (right / left) dualism model, he strives to find a way to legitimize Marx's philosophy. In the article "Marx in the modern world" ("Marx in the modern world"), on the one hand, he asserted the value of this philosophy, but on the other hand, disagreed with the way of understanding, applying too descriptive and propose a theory on post-marxist historical materialism (post-marxist materialism). That way, he continues to present quite concentrically in the second volume of The Nation-State and Violence (State and Violence) on the history of formation and development of nations - the people of today modern, a phenomenon that, according to him, was born in the Marx period that had not been deepened.

In the structuralist line, but still influenced by Lyotard's analysis. He said that historical materialistic ideology in particular, Marxism in general, was understood very differently for many different groups of people. Around the world, there are many different versions of Marxism. However, there are two basic interpretations. The first trend, the so-called economic version, is the interpretation of some particular historical change process. This tendency group asserts that the general process of history is influenced more or less by the infrastructure of society, or influenced by the prerequisite of class struggle. He cites a statement by Marx as a representative statement for this version, that since there was class, "human history is the history of class struggle". The second version of historical materialism is more philosophical, its focus is to advocate not only understanding history but changing history itself; the more understanding of historical conditions, the more likely it is to win a future to suit the interests of mankind. If the first can be said to be more or less attached to those who interpret Marxism as a scientific doctrine, then this second version attaches to those who conceive of Marxism, first of all a critical method. This tendency does not place heavy emphasis on both the content of Marx's statements and contemporary capitalism or the content of history itself, but sees Marxism as, above all, a critique of processes of change. After all, either "great narrative" or some kind of ideology, only.

Despite promoting and encouraging the application of historical materialism, Giddens argued that Marxist theory was difficult to predict and control the future, because history evolved according to the law of accumulation of knowledge, and not all. Economic dynamics are class power, because there is also the power of the information revolution, national nation, culture, historical characteristics, and so on. In short, the transformation of social regimes from primitive communes to socialist is just a rule of a certain kind of society, not a general rule for the whole calendar. human history, on a path in the course of time.

\footnotetext{
${ }^{3}$ The neo-Marxist social theory in Germany criticized the dogmatic group, imitating Marx's ideas, just to defend the communist parties. orthodox and advocate a different direction for social development, following the radical leftist stance, with critical theory
} 
Thus, on the stance of Marx's philosophy, it is possible to summarize the basic generalization of the postmodern situation: postmodern critics of science with two related arguments: one is related to knowledge (coistémologie) one related to ideology (idéologie). Both are based on subjectivism. Melford Spiro (1920-2014), the critic, American cultural anthropology, has a similar explanation: First, because of the subjectivity of the human subject, it cannot be a science; and in all circumstances, the subjectivity of the subject all excludes science's ability to discover objective truths. Next, according to the second argument, as a means of power, it eliminates the subjectivity of oppressed groups, women, ethnic minorities, people of the developing world.

In the name of the postmodern situation, many people seek to deny Marx philosophy, but some cannot be all. Jacques Derrida (1930 - 2004), initiator of deconstruction. Derrida had a great influence on human science, especially postmodern theory. This Jewish-born French philosopher, at a seminar in the United States, 1993, under the theme: Whither Marxism? (Where Does Marxism Go?) Gave in two one lecture: Spectres de Marx (The Ghosts of Marx). Although there are many conflicting opinions surrounding this topic by Derrida, it must be seen that this is a critique of what postmodern philosophers say about Marx and Marx's philosophy. That seminar meant the end of communist society, so Derrida found it necessary to reiterate the Declaration of the Communist Party ${ }^{4}$ which begins with the sentence: A ghost haunting Europe: the specter of communism (Ein Gespenst geht um in Europa. - das Gespenst des Kommunismus!) (Mark, C. \& Angghen, Ph., 1995, p.595). To eliminate that specter, the whole of Europe had to merge into a divine alliance, because they admitted "it is a force". Reading Spectres de Marx, we see that Derrida borrowed ghost images to analyze, represent the shadow of the past now present in the present (Derrida called the living present - le présent vivant), and the present there is still present (le présent passé) simultaneously with what will come in the future, so that present seems to become something different from it.

He speaks of ghosts, not to return to the unconscious that dominates the psychoanalysis of Sigmund Freud (1856-1939), but to show a temporal relationship between past, present, future ; First, the living present is a connection between the past and the future.

Only to note, when recalling Marx's specter, Derrida recommends: The ghost has become a force of old Europe associated with revolutionary Marxism and science, not Marxist dogmatism, stubbornly, quoting "from master narrative". He himself reiterated Marx and Engels talking about the historical nature of their own writings and writings. That serves as a warning for future readers. A tomorrow's transformation of the thesis, not to see the author's knowledge enriched, remains abundant in the fixed system, but rather the 'rupture or reconstruction' (ruptere ou de restructuration) (Derrida, J., 1993, p. 35) and ready to receive, beyond all possible structures, beyond all human expectations, new knowledge, new techniques, and even the political environment is deformed. So that, "It will always be a mistake if we cannot read and re-read, discussing Marx's works - maybe along with someone else's writings, but it must be out of the way of reading or formal conference".

There is no ideological future, he asserts, if we do not return to Marx, deduce the past, his entire legacy. But it is also possible that we just need to find a return to a certain spirit of Marx, with all

\footnotetext{
${ }^{4}$ C. Marx and Angels wrote in December 1847- January 1848. Here is a document of the essence of scientific communism.
} 
his genius, one ghost in many, the ghosts of Marx. Because, as he said, it is one of our assumptions or rather our bias. (Derrida, J., 1993, p. 36).

Derrida is typical of the pre-modern generation, when in the late 1950s, there were people who were caught between two orthodoxism at that time. After the 1991 incident, in negating the postmodernist trend of the neo-rightist Fukuyama faction, Derrida went back to the past and acknowledged the Marxist element of deconstruction. Recognizing himself as a post-Marxist, he made his stance clear, never opposed to Marxism and has always embraced the spirit of resistance of Marxism.

With the passing of the presence of postmodern as well as its conception of the legitimization of science and knowledge, it is easy to see that it is a theory associated with a historical period, when information technology and communication took the throne. More than five decades in existence, but this theory only really sheds light in recent times. Of course, there are many opinions assessing it: there are people, there are fields, they are considered progress, but also people, some areas consider escapism, paranoia. However, postmodernism has to deal with, both proposing "the new thing" and combining traditional ideas, so there are aspects of the past and the modern. But due to its lack of character, it fell into eclecticism (to eclet). In the history of philosophy, eclecticism has many forms, but Ph.ngghen has pointed out that, although "different compete with each other", eclecticism "is the same in one point that all the These are fragments of old philosophies that are patched up and all are metaphysical "(Mark, C. \& Angghen, Ph., 2004, p.490).

Postmodernism is basically both a continuation and a transcendence of the modern. Its presence is double coding (Jencks, Charles, 1996, pp.26-30), which requires a reference to both code and context, opening up to two different interpretations depending on the reference frame is used to explain it. Because of this manifold, its pluralism more clearly emphasizes its pluralism. In the midst of that union, postmodernists set sail, often lost and lost, though they sometimes realized the great promise of a pluralistic culture with so much freedom. Therefore, postmodern or any philosophy, will "no longer have a way out, no longer have any ability to see light without giving up metaphysical thinking and returning to critical thinking by one way or another ". (Mark, C. \& Angels, Ph., 2004, p.490).

Can we imagine how the postmodern era will end? Even the beginning of it cannot be determined. But what we have been seeing is its constant entanglement in modernity, showing that postmodern is a continuation of modernity and its transcendence. It is almost exclusively postmodern, is a continuation of modernity in its ultimate or exaggerated form only. Michel Foucault (1926 - 1984), a French philosopher, before his death, called for a reconsideration of the Enlightenment. Moreover, the conscientious also realized that, accordingly, to reconsider Kant, and then "take Hegel from right-wing liberals like Fukuyama," would eventually return to Marx. Even in Vietnam, in the noise of the postmodern era, since the 1960s, someone has noticed: "Perhaps very few characters make a strong resonance like Karl Marx. His doctrine is not only a system of ideas for the scholar to contemplate the beautifully balanced form”. When talking about Marx, it is necessary to talk about practice. Practice does not mean spontaneous activity, self-service; but is active in a fair sense of humanity's ultimate meaning. It is precisely because Marx's doctrine requires entry into the world, but the world may bear its trail" (Tran Van Toan, 1965, p.6). Returning to Marx - it is very important to repeat Derrida's words - deduce the past, the whole block of his legacy. But it is also possible that we just need to find a return to a 
certain spirit of Marx, with all his geniuses, a specter in a lot. Perhaps this ghost is the remedy for our ideological future.

\section{Conclusion}

The presence of postmodern and postmodern philosophy in the second half of the twentieth century partly responded to the development of modern Western philosophy and its transforming impact. It contributes a very important voice in the criticism of the flaws and contradictions in traditional philosophy, from Nietzsche onwards, at the same time, it also suggests a new way of thinking for modern philosophy. However, from the beginning, "postmodernity" is a noun with many shortcomings and lack of clarity. It seeps into history with a sense of tradition, and then lags on the problems it poses. Is the unreasonable "postmodernity" just a trendy "fashion", not a "good way" for the future of modern Western philosophy?

\section{Acknowledgement}

We would like to express the anonymous research participants for their willingness to have taken part in this study. Additionally, our sincere gratitude should go to other relevant parties who have given comments and supported us during our study. Without their unconditional help and support, we would have never been able to finish this study.

\section{References}

1. Bertens, Hans. (1995). The idea of the postmodern: A history. London and New York: Routledge,

2. Deleuze, Gilles. (2010). Nietzsche and philosophy. (Translated by Nguyen Thi Tu Huy, edited by Bui Van Nam Son). Hanoi, Vietnam: Knowledge.

3. Derrida, Jacques. (1993). Spectres de Marx. Paris: Éditions Galilée.

4. Giddens, Anthony. (1997). Marx in the modern world. Socialist Review, issue 210, July/August.

5. Irvine, Martin. (1998). "The Postmodern", "Postmodernism”, "Postmodernity" Approaches to Po-Mo. Retrieved from http://faculty.georgetown.edu/irvinem/theory/pomo.html

6. Jameson, Frederic. (1991). Postmodernism, or, the Cultural Logic of Late Capitalism, Durham, NC: Duke University Press.

7. Le Huy Bac. (2017). Postmodern literature, theory and reception. Hanoi, Vietnam: University of Education.

8. Lyotard, Jean-Francois. (1979). La condition postmoderne: rapport sur savoir. Paris: Les Editions de Minut.

9. Lyotard, Jean-Francois. (1984). The Postmodern Condition: A Report on Knowledge. (Translation from the French by Geoff Bennington and Brian Massumi Freword by Fredrc Jameson). Manchester: Manchester University Press.

10. Lyotard, Jean-François. (1986). Le postmoderne explique aux enfants:

Correspondance 1982-1985. Paris: Éditions Galilée.

11. Lyotard, Jean-Francois. (2007). Post-modern situation (Translated by Ngan Xuyen, edited by Bui Van Nam Son). Hanoi, Vietnam: Knowledge.

12. Malpas, Simon. (2005). The Postmodern (The New Critical Idiom). London and New York: Routledge. 
13. Marx, C., \& Angels, Ph. (1995).Complete Works, Episode 4. Hanoi, Vietnam: National politics - Truth.

14. Marx, C. \& Angels, Ph. (2004). Complete Works, Episode 20. Hanoi, Vietnam: National politics - Truth.

15. Tran Van Toan. (1965). Learn about Karl Marx's philosophy. (Social research bookcase). Saigon, Vietnam: Nam Son. 